\title{
WSTĘPNE BADANIE PRACOCHŁONNOŚCI WYKONANIA PRZEGRODY Z WIELKOWYMIAROWYCH ELEMENTÓW SILIKATOWYCH
}

\author{
Wojciech Rogala \\ Wydział Inżynierii Lądowej, Politechnika Warszawska, Warszawa
}

\begin{abstract}
STRESZCZENIE
W artykule przedstawiono wstępne badanie pracochłonności wykonania ścian z wielkowymiarowych elementów wapienno-piaskowych. Celem badań było zweryfikowanie czasu murowania przegród z elementów, które są pięciokrotnie większe od standardowo stosowanych bloczków oraz są murowane za pomocą miniżurawia. Pilotażowe badania przeprowadzono za pomocą dwóch metod - sumarycznej i analityczno-badawczej. Wyniki badań odniesiono do istniejących katalogów nakładów rzeczowych. W artykule zaproponowano uproszenie formuły kalkulacyjnej, która jest wykorzystywana do wyznaczenia nakładów robocizny na murowanie ścian w opisywanej technologii.
\end{abstract}

Słowa kluczowe: wielkowymiarowe elementy silikatowe, normowanie nakładów rzeczowych, mechanizacja murowania, czas wznoszenia ścian, silikaty

\section{WSTĘP}

W ostatnich latach jednym z najczęściej występujących problemów na polskich budowach jest brak wystarczającej liczby pracowników fizycznych. W trzecim kwartale 2018 roku w Polsce było prawie 26 tys. wolnych miejsc pracy w budownictwie (Eurostat, 2018). Według innych danych w Polsce w branży budowlanej brakuje nawet 120-150 tys. pracowników (PAP, 2018). Brak rąk do pracy przyczynia się do znacznego wzrostu cen usług budowlanych, opóźnień w realizacji kontraktów oraz spadku jakości usług. Co więcej, brak pracowników fizycznych na rynku pracy stanowi barierę dla dalszego rozwoju gospodarki.

Jednocześnie budownictwo, poza rolnictwem, jest najbardziej odpornym na zmiany działem gospodarki (Nurzyński, 2011). Wiele technologii nie zmieniło się istotnie w przeciągu ostatnich kilkudziesięciu lat.
Wśród takich technologii znajduje się bez wątpienia murowanie ścian. Co prawda, elementy murowe zostały zmodyfikowane - są wyposażone w uchwyty montażowe, pióro i wpust oraz mają znaczną dokładność wymiarową (co pozwala na murowanie na cienką spoinę). Pomimo tego wciąż wznoszenie ścian należy do jednej z bardziej pracochłonnych robót budowlanych, wymagających dużego wysiłku fizycznego.

W ostatnich latach obserwowany jest znaczny wzrost udziału silikatów w rynku przegród budowlanych (Misiewicz, 2016; 2018), głównie z uwagi na dobre parametry izolacyjności akustycznej. Bardzo duża izolacyjność akustyczna przegród wynika $\mathrm{z}$ wysokiej gęstości (DIN 4109:2016-07), która jednak przyczynia się do zwiększonej uciążliwości prac murarskich. Średniej wielkości budynek jednorodzinny z bloków wapienno-piaskowych to ok. 80 t elementów murowych, które murarz musi przenieść z palety do miejsca wmurowania.

$\varpi_{\text {wrogala@il.pw.edu.pl }}$ 
Rogala, W. (2019). Wstępne badanie pracochłonności wykonania przegrody z wielkowymiarowych elementów silikatowych. Acta Sci. Pol. Architectura 18 (2), 43-50, DOI: 10.22630/ASPA.2019.18.2.21

Murarze są jedną z bardziej poszukiwanych specjalności na rynku pracy (Wielkiebudowanie.pl, 2019). Ograniczenia w dostępności murarzy w tym przypadku wpływają bezpośrednio na czas realizacji obiektu, ponieważ murowanie ścian leży zwykle na ścieżce krytycznej realizacji przedsięwzięcia.

W porównaniu do Polski przegrody wznoszone w krajach Europy Zachodniej nieco się różnią. Grubość ścian konstrukcyjnych jest mniejsza, a technologie montażu elementów scalonych i prefabrykowanych, które przyśpieszają lub mechanizują montaż, cieszą się znacznie większą popularnością. Wśród takich technologii znajduje się murowanie przegród z wielowymiarowych bloków wapienno-piaskowych. Technologia została wprowadzona do Polski w 2012 roku, ale obecnie stanowi zaledwie ok. 0,1\% udziału w rynku sprzedawanych materiałów budowlanych. Technologia wznoszenia wielkowymiarowych bloków wapienno-piaskowych z uwagi na duże wymiary i masę elementów jest częściowo zmechanizowana. Do ich wznoszenia używa się miniżurawi, dzięki czemu pracownicy nie przenoszą elementów murowych. W Niemczech udział elementów wielkowymiarowych w sprzedaży bloków wapienno-piaskowych wynosi ponad $50 \%$.

Dostępne w Polsce wielowymiarowe elementy mają powierzchnię okołopięciokrotnie większą od tradycyjnie wykorzystywanych bloków wapienno-piaskowych (Harassek i Rogala, 2014). Z tego względu budowa przegród przebiega szybciej oraz przy zaangażowaniu mniejszej liczby brygad roboczych. W badaniach zweryfikowano rzeczywisty czas wznoszenia przegród z bloków wielkowymiarowych i porównano $\mathrm{z}$ danymi prezentowanymi przez producenta.

\section{MATERIA $\longleftarrow$ I METODY}

Producent elementów firma Xella Polska wprowadzając produkt na rynek, opracował katalog nakładów rzeczowych KNR K-50. Obecnie katalogi nakładów rzeczowych mają coraz bardziej ograniczone zastosowanie, niemniej jednak w omawianym przypadku, przy wprowadzaniu nowej technologii, mogą dostarczać danych i argumentów przemawiających za jej używaniem. Dane zawarte w katalogu zgodnie $\mathrm{z}$ deklaracją producenta wynikają $\mathrm{z}$ rzeczywistych pomiarów wykonywanych na budowie. Według danych zawartych w katalogu norma nakładu pracy na murowanie przegrody $\mathrm{z}$ elementów wielowymiarowych jest nawet pięciokrotnie mniejsza od przegrody $\mathrm{z}$ drobnowymiarowych elementów silikatowych (KNR K-28).

Według KNR K-50 nakłady rzeczowe należy ustalić, sumując nakłady na murowanie z elementów wielkowymiarowych, wykonanie pierwszej warstwy, wykonanie warstw uzupełniajacych oraz wykonanie otworów. Można to opisać za pomocą zależności:

$N_{c}=\frac{N_{c L} \cdot A_{L}+N_{c F} \cdot L_{F}+N_{c S} \cdot L_{s} \cdot n_{S}+N_{c C} \cdot A_{C}+N_{c O w} \cdot n_{O w} \cdot N_{c O d} \cdot n_{O d}}{A}$

gdzie:

$N_{c}$ - norma nakładu pracy na wykonanie $1 \mathrm{~m}^{2}$ muru $\mathrm{z}$ otworami,

$N_{c L}$ - norma nakładu pracy na wykonanie $1 \mathrm{~m}^{2}$ ściany z elementów wielkowymiarowych bez otworów (w przypadku budynków wielokondygnacyjnych $\left.N_{c}=0,28\right)\left[\mathrm{rbh} \cdot \mathrm{m}^{-2}\right]$,

$A_{L}$ - łączna powierzchnia przegrody z elementów wielkowymiarowych bez otworów $\left[\mathrm{m}^{2}\right]$,

$N_{c F}$ - norma nakładu pracy na wykonanie pierwszej warstwy muru $\left[\mathrm{rbh} \cdot \mathrm{m}^{-1}\right]$,

$L_{F}$ - łączna długość pierwszej warstwy muru [m],

$N_{c S}$ - norma nakładu pracy na wykonanie warstwy uzupełniającej muru $\left[\mathrm{rbh} \cdot \mathrm{m}^{-1}\right]$,

$L_{S}$ - łączna długość warstwy uzupełniającej muru [m],

$n_{S}$ - liczba warstw uzupełniających w murze [szt.], $N_{c C}$ - norma nakładu pracy na wykonanie $1 \mathrm{~m}^{2}$ uzupełnień $\mathrm{z}$ elementów drobnowymiarowych $\left[\mathrm{rbh} \cdot \mathrm{m}^{-2}\right]$, $A_{C}$ - łączna powierzchnia uzupełnień z elementów drobnowymiarowych $\left[\mathrm{m}^{2}\right]$,

$N_{c O w}$ - norma nakładu pracy na wykonanie otworów okiennych [rbh·szt. ${ }^{-1}$,

$n_{O w}-$ liczba otworów okiennych [szt.],

$N_{c O d}$ - norma nakładu pracy na wykonanie otworów drzwiowych [rbh·szt. ${ }^{-1}$,

$n_{O d}-$ liczba otworów drzwiowych [szt.],

$A$ - łączna powierzchnia muru z otworami $\left[\mathrm{m}^{2}\right]$.

Obecnie roboty murowe są najczęściej realizowane przez niewielkie firmy podwykonawcze. Niewielkie firmy wyspecjalizowane $\mathrm{w}$ murowaniu nie korzysta- 
Rogala, W. (2019). Wstępne badanie pracochłonności wykonania przegrody z wielkowymiarowych elementów silikatowych. Acta Sci. Pol. Architectura 18 (2), 43-50, DOI: 10.22630/ASPA.2019.18.2.21

ją z programów do kosztorysowania, dlatego z uwagi na poziom skomplikowania powyższej zależności obliczanie pracochłonności na wykonanie $1 \mathrm{~m}^{2}$ muru jest zwykle pomijane i w praktyce kalkulacja danych do harmonogramu sprowadza się do podzielenia spodziewanej pracochłonności na wykonanie przegrody z elementów drobnowymiarowych przez 2.

Wiele prac badawczych wskazuje na konieczność oceny wiarygodności norm (Koper i Marcinkowski, 2013). Badania normy nakładu pracy przeprowadzono, wykorzystując dwie metody - analityczno-badawczą oraz sumaryczną (Hoła i Mrozowicz, 2003). Metoda analityczno-badawczą wyznaczono normy nakładu pracy na wykonanie operacji roboczych, a metode sumaryczną na wykonanie konkretnej przegrody. W pierwszej kolejności wykonano chronometraż robót i podzielono prace murarskie na operacje robocze. Wypracowany optymalny schemat organizacji pracy zakłada w pierwszej kolejności murowanie pierwszej warstwy na całej kondygnacji, a następnie murowanie elementów wielowymiarowych. Pierwsza warstwa pozostaje nieuzupełniona jedynie w miejscu przejaz- du miniżurawia. W ten sposób redukuje się przestoje technologiczne spowodowane czasem potrzebnym na związanie zaprawy ogólnego stosowania, na której wznoszona jest pierwsza warstwa muru. Dzięki takiej organizacji prac redukuje się też czas przemieszczania miniżurawia na inne stanowisko robocze. Murowanie pierwszej warstwy nie różni się od tradycyjnego murowania $\mathrm{z}$ elementów drobnowymiarowych, dlatego nakłady potrzebne na wykonanie pierwszej warstwy przyjęto na podstawie KNR K-28, a pomiarów dokonano jedynie dla elementów wielkowymiarowych. Podział procesu roboczego (Koper, 2013) na operacje robocze przedstawia rysunek 1 .

Technologia zakłada murowanie $\mathrm{z}$ bloków pełnych $(50 \times 60 \mathrm{~cm}), 3 / 4$ oraz połówkowych. Długości ścian spoza modułu $25 \mathrm{~cm}$ sa uzupełniane za pomoca docinanych elementów drobnowymiarowych, ułożonych w trzech warstwach na wysokości $60 \mathrm{~cm}$ lub za pomoca spoiny pionowej o szerokości maksymalnie $15 \mathrm{~mm}$ (PN-EN 1996-1-1:2015-06). Rozłożenie zaprawy uwzględniono w pozycjach 1.1 oraz 1.2 zaprezentowanych na rysunku 1.

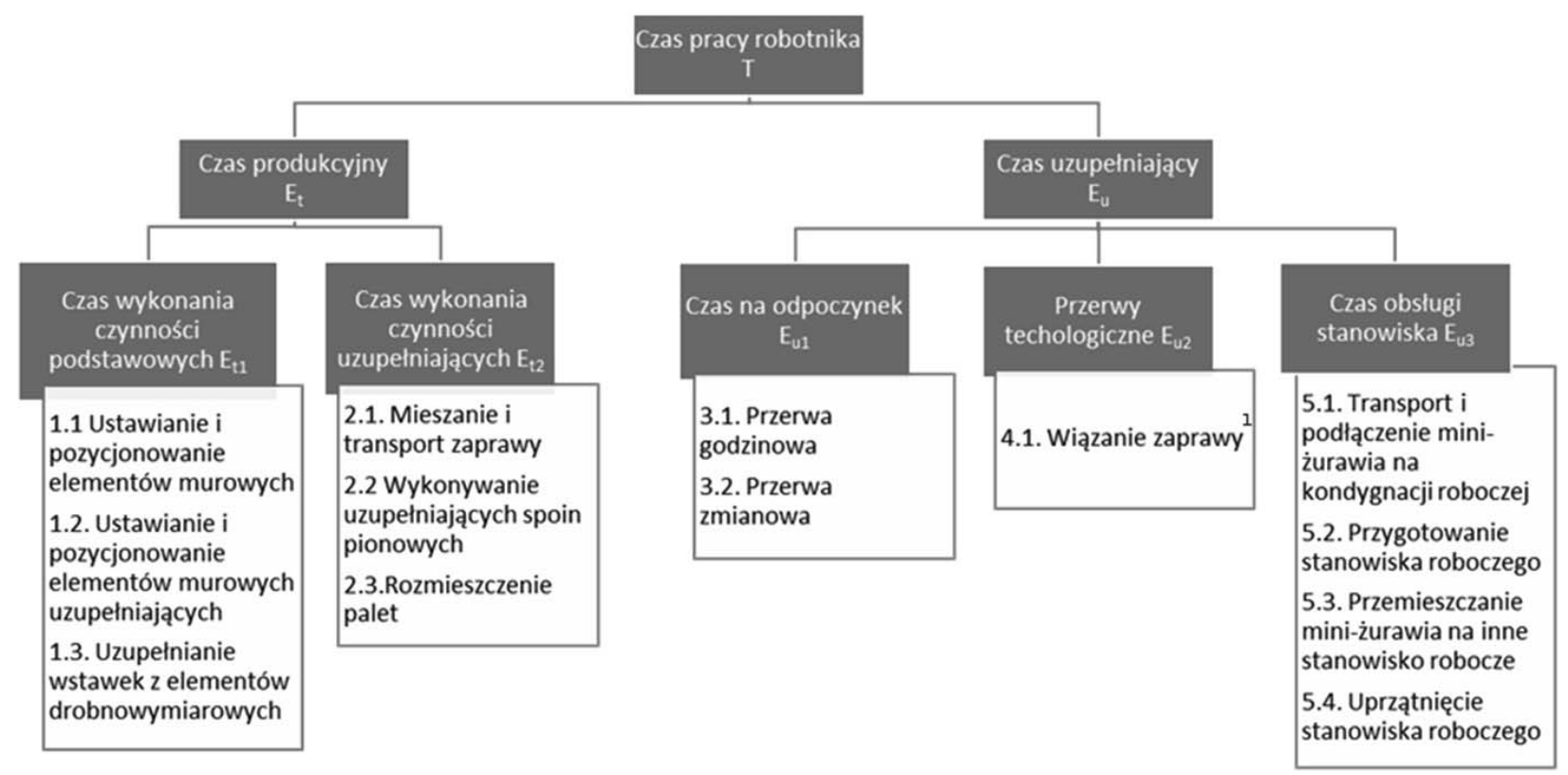

${ }^{1} \mathrm{~W}$ budownictwie przyjęto zasadę, że czas przerw technologicznych nie jest ujmowany w normach. W trakcie wiązania zaprawy prace murarskie są kontynuowane na innych frontach robót.

Rys 1. Rozkład procesu roboczego na operacje robocze

Fig. 1. Distribution of the working process for working operations 
Rogala, W. (2019). Wstępne badanie pracochłonności wykonania przegrody z wielkowymiarowych elementów silikatowych. Acta Sci. Pol. Architectura 18 (2), 43-50, DOI: 10.22630/ASPA.2019.18.2.21

Wśród czynności uzupełniających nie uwzględniono czasu potrzebnego na wykonanie planów montażowych (producent dostarcza plany montażowe zawierające układ poszczególnych elementów w konkretnej przegrodzie). Murowanie z użyciem planów przyśpiesza realizację, skraca przygotowanie inwestycji oraz przyczynia się do dokładnego określenia zapotrzebowania budowy na elementy murowe. Rola murarza ogranicza się do ustawienia elementów murowych zgodnie z dostarczoną instrukcją montażu, co dodatkowo przyśpiesza proces murowania. Kodeks pracy określa przysługująca pracownikowi piętnastominutową przerwę wliczoną $\mathrm{w}$ czas pracy. $\mathrm{W}$ obliczeniach dodatkowo założono pięciominutową przerwę na każdą godzinę pracy.

Badania metoda analityczno-badawczą dokonano przy budowie czwartej kondygnacji naziemnej budynku wielorodzinnego w Zielonej Górze. Liczbę poszczególnych operacji roboczych na $1 \mathrm{~m}^{2}$ oszacowano na podstawie planów montażowych dla czterokondygnacyjnego budynku w łącznej powierzchni ścian $4560 \mathrm{~m}^{2}$. Dane odnoszą się do prac prowadzonych przez zespół murarski dwuosobowy.

Badania metodą analityczno-badawczą uzupełniono o badania metodą sumaryczną. W tym celu przeanalizowano efekty pracy trwającej $8,5 \mathrm{~h}$ zmiany przy murowaniu ścian opisanego wcześniej budynku. Prace murarskie były prowadzone przez dwuosobową brygadę, mało doświadczoną $\mathrm{w}$ pracy $\mathrm{z}$ nową technologią. W kolejnym etapie przeanalizowano czas całkowity budowy przegrody o powierzchni $8,7 \mathrm{~m}^{2}$ (wykonywanej na placu składowym przy zakładzie produkcyjnym), wznoszonej przez murarzy z dużym doświadczeniem stosowania opisywanej technologii. Uzyskaną w ten sposób normę nakładu pracy odniesiono do danych uzyskanych za pomocą metody analityczno-badawczej i danych zawartych w KNR K-50.

\section{WYNIKI}

Wyniki pomiaru czasu trwania operacji roboczych potrzebnych do wyznaczenia czasu murowania za pomocą metody analityczno-badawczej zaprezentowano w tabeli 1. Podczas dokonywania pomiarów zaobserwowano duże rozbieżności przy kolejnych pomiarach czasu trwania operacji roboczych. Rozbieżności wy- nikają m.in. z innego usytuowania palet, konieczności dostarczenia dodatkowej ilości wody do przygotowania zaprawy oraz oczekiwania na dostępność żurawia.

Na podstawie uzyskanych wyników można oszacować łączną pracochłonność wykonania przegród o powierzchni $4560 \mathrm{~m}^{2}$ na $2238 \mathrm{rbh}$, co odpowiada normie nakładu pracy $N_{c}=0,473 \mathrm{rbh} \cdot \mathrm{m}^{-2}$. Należy również zauważyć, że podana struktura czasu pracy i badanie odnosi się do pracy żywej, a nie maszyny montażowej. Przy pomiarze robót zaobserwowano duże przestoje $\mathrm{w}$ murowaniu, związane $\mathrm{z}$ transportem wewnętrznym palet.

Uzyskany wynik jest wyższy od wartości prezentowanej w KNR K-50 $\left(N_{c}=0,28 \mathrm{rbh} \cdot \mathrm{m}^{-2}\right)$, choć uwzględnia także oblicowanie otworów, na które KNR K-50 przewiduje dodatkową wartość (po uwzględnieniu nakładu pracy potrzebnego na oblicowanie otworów $N_{c}=0,37 \mathrm{rbh} \cdot \mathrm{m}^{-2}$ ). Należy również zauważyć, że pomiarów dokonano przy wznoszeniu ściany zewnętrznej, która ma znacznie więcej otworów i elementów uzupełniających niż ściany wewnętrzne. Obliczając $N_{c}$ jedynie dla ścian zewnętrznych na podstawie KNR $\mathrm{K}-50$, otrzymuje się wartość $0,42 \mathrm{rbh} \cdot \mathrm{m}^{-2}$.

Wyniki zastosowania metody sumarycznej do wyznaczenia normy nakładu pracy zaprezentowano $\mathrm{w}$ tabeli 2. Uzyskano znaczną rozbieżność między normą wydajności zmianowej robót murarskich na budynku w Zielonej Górze i przegrodą murowaną na placu składowym. Rozbieżność wynika z trzech czynników - doświadczenia zespołu roboczego, pracy na wysokości i ograniczeń związanych z BHP oraz czasu potrzebnego na dostarczenie palet. W pierwszym przypadku murarze byli odpowiedzialni za transport wewnętrzny palet, co znacznie spowolniło prace. Dodatkowo zaprawa była przygotowywana przez jednego pracownika, powodując przestój w pracy drugiego członka brygady. $\mathrm{W}$ drugim przypadku pomierzony czas nie uwzględniał transportu wewnętrznego palet, które w momencie rozpoczęcia robót znajdowały się na stanowisku roboczym murarzy. $Z$ uwagi na niewielką wysokość muru podczas przygotowywania zaprawy drugi murarz mógł samodzielnie prowadzić prace murarskie. W dwóch przypadkach w ścianie wykonano przekrycie otworów za pomoca prefabrykowanych nadproży, co zostało uwzględnione w obliczeniach teoretycznego czasu murowania, wyznaczonego na podstawie KNR K-50 oraz KNR BC-01. 
Rogala, W. (2019). Wstępne badanie pracochłonności wykonania przegrody z wielkowymiarowych elementów silikatowych. Acta Sci. Pol. Architectura 18 (2), 43-50, DOI: 10.22630/ASPA.2019.18.2.21

Tabela 1. Wyniki pomiarów czasu operacji roboczych składających się na murowanie z elementów wielkowymiarowych - budynek wielorodzinny w Zielonej Górze

Table 1. The results of time measurement of working operations performer for large masonry units bricklaying - multifamily house in Zielona Góra

\begin{tabular}{|c|c|c|c|c|c|c|c|c|c|}
\hline \multirow{2}{*}{$\begin{array}{l}\text { Operacja } \\
\text { robocza } \\
\text { Working } \\
\text { operation }\end{array}$} & \multirow{2}{*}{$\begin{array}{c}\text { Częstość występowania } \\
\text { Frequency }\end{array}$} & \multicolumn{4}{|c|}{ Czas - Duration [s] } & \multirow{2}{*}{$\begin{array}{l}\text { Ilość na } 1 \mathrm{~m}^{2} \\
\text { Expenditure } \\
\text { per } 1 \mathrm{~m}^{2}\end{array}$} & \multirow{2}{*}{$\begin{array}{c}\text { Całkowita } \\
\text { ilość [jedn.] } \\
\text { Total amount } \\
\text { [pcs.] }\end{array}$} & \multirow{2}{*}{$\begin{array}{l}\text { Średnia } \\
\text { Average } \\
\quad[\mathrm{s}]\end{array}$} & \multirow{2}{*}{$\begin{array}{l}\text { Czas na } 1 \mathrm{~m}^{2} \\
\text { Duration } \\
\text { per } 1 \mathrm{~m}^{2}\end{array}$} \\
\hline & & 1 & 2 & 3 & 4 & & & & \\
\hline 1.1 & $\begin{array}{l}2,9 \text { szt. na } 1 \mathrm{~m}^{2} \\
2.9 \text { pcs per } 1 \mathrm{~m}^{2}\end{array}$ & 120 & 100 & 180 & 110 & 2,9 & 14200 & 117,5 & 340,5 \\
\hline 1.2 & $\begin{array}{c}0,65 \text { szt. na } 1 \mathrm{~m}^{2} \\
0.65 \text { pcs. per } 1 \mathrm{~m}^{2}\end{array}$ & 140 & 120 & 220 & 200 & 0,65 & 2600 & 170 & 110,5 \\
\hline 1.3 & $\begin{array}{l}0,15 \text { szt. na } 1 \mathrm{~m}^{2} \\
0.15 \text { pcs. per } 1 \mathrm{~m}^{2}\end{array}$ & 1080 & - & - & - & 0,008 & 480 & 1080 & 8,6 \\
\hline 2.1 & $\begin{array}{l}\text { każde } 14 \mathrm{~m}^{2} \text { muru } \\
\text { each } 14 \mathrm{~m}^{2} \text { of masonry }\end{array}$ & 720 & 650 & 740 & 700 & 0,071 & 286 & 702,5 & 50,2 \\
\hline 2.2 & $\begin{array}{c}0,05 \text { szt. na } 1 \mathrm{~m}^{2} \\
0.05 \text { pcs. per } 1 \mathrm{~m}^{2}\end{array}$ & 600 & - & - & - & 0,001 & 200 & 600 & 0,4 \\
\hline 2.3 & $\begin{array}{l}\text { każda paleta } \\
\text { each pallete }\end{array}$ & 600 & 900 & 720 & 660 & 0,289 & 1154 & 720 & 207,7 \\
\hline 3.1 & $\begin{array}{l}\text { każda godzina } \\
\text { each hour }\end{array}$ & 5 & - & - & - & 0,083 & \multirow{2}{*}{\multicolumn{3}{|c|}{$\begin{array}{l}\text { obliczone jako dodatek } \% \text { do całkowitego czasu } \\
\text { murowania } \\
\text { calculated as a } \% \text { of the total masonry time }\end{array}$}} \\
\hline 3.2 & $\begin{array}{c}\text { zmiana } 8 \mathrm{~h} \\
\text { each } 8 \text {-hour shift }\end{array}$ & 15 & - & - & - & 0,031 & & & \\
\hline 5.1 & $\begin{array}{c}\text { każda kondygnacja } \\
\text { each floor }\end{array}$ & 3600 & - & - & - & 0,002 & 8 & 3600 & 7,2 \\
\hline 5.2 & \multirow{3}{*}{$\begin{array}{l}\text { każda zmiana stanowiska } \\
\text { roboczego } \\
\text { each workplace shift }\end{array}$} & 900 & - & - & - & 0,019 & 75 & 900 & 16,9 \\
\hline 5.3 & & 900 & - & - & - & 0,019 & 75 & 900 & 16,9 \\
\hline 5.4 & & 600 & - & - & - & 0,019 & 75 & 600 & 11,3 \\
\hline
\end{tabular}

Tabela 2. Wyniki pomiarów metodą sumaryczną

Table 2. Results of summary method

\begin{tabular}{lcc}
\hline Parametr - Parameter & $\begin{array}{c}\text { Pomiar 1 } \\
\text { Measurement 1 }\end{array}$ & $\begin{array}{c}\text { Pomiar 2 } \\
\text { Measurement 2 }\end{array}$ \\
\hline Powierzchnia muru z otworami - Surface of masonry including openings $\left[\mathrm{m}^{2}\right]$ & 42,48 & 8,7 \\
\hline Powierzchnia muru bez otworów - Surface of masonry excluding openings $\left[\mathrm{m}^{2}\right]$ & 37,98 & 7,16 \\
\hline Liczba otworów [szt.] - Openings quantity [pcs.] & 2 & 1 \\
\hline Czas murowania - Bicklaying time [h] & 8,5 & 0,7 \\
\hline Teoretyczny czas murowania - Theoritical time of bricklaying $[\mathrm{h}]$ & 6,66 & 1,67 \\
\hline$N_{c}\left[\mathrm{rbh} \cdot \mathrm{m}^{-2}\right],\left[\mathrm{mhr} \cdot \mathrm{m}^{-2}\right]$ & 0,405 & 0,084 \\
\hline
\end{tabular}


Rogala, W. (2019). Wstępne badanie pracochłonności wykonania przegrody z wielkowymiarowych elementów silikatowych. Acta Sci. Pol. Architectura 18 (2), 43-50, DOI: 10.22630/ASPA.2019.18.2.21

\section{PODSUMOWANIE I DYSKUSJA}

Czas murowania ścian z bloków wielowymiarowych jest znacznie krótszy niż w przypadku murowania z elementów drobnowymiarowych. W praktyce czas potrzebny na transport wewnętrzny jednak jest zbliżony, ponieważ zależy jedynie od ilości materiału umieszczonego na palecie. Z uwagi na skrócony czas murowania procentowy udział transportu wewnętrznego w robotach murarskich wynosi aż 25\% (rys. 2). Odejmując czas na dostarczenie palet i przerwy na odpoczynek, które mogą mieć inny wymiar w poszczególnych firmach, nakłady uzyskane za pomocą metody analityczno-badawczej jedynie na murowanie wynoszą $0,31 \mathrm{rbh} \cdot \mathrm{m}^{-2}$. Bardzo duży wpływ ma także doświadczenie murujących zespołów roboczych i organizacja czasu pracy.

Uzyskana norma nakładu pracy w analitycznobadawczej i sumarycznej metodzie jest nieznacznie wyższa od normy wyznaczonej na podstawie KNR $\mathrm{K}-50$ (od 0,38 do $0,42 \mathrm{rbh} \cdot \mathrm{m}^{-2} \mathrm{w}$ zależności od liczby otworów).

Korekty w dostępnym katalogu wymaga niewątpliwie czas na wykonanie uzupełnień z elementów drobnowymiarowych, określony w KNR K-50 jako $0,8 \mathrm{rbh} \cdot \mathrm{m}^{-2}$. Dla porównana KNR K-28 określa nakłady potrzebne na wykonane $1 \mathrm{~m}^{2}$ muru $\mathrm{z}$ elementów drobnowymiarowych na $1,24 \mathrm{rbh} \cdot \mathrm{m}^{-2}$. Paleta z elementami drobnowymiarowymi znajduje się poza stanowiskiem roboczym, co wydłuża czas realizacji.
Dodatkowo uzupełnienia $\mathrm{z}$ elementów drobnowymiarowych zwykle wymagają przycinania, dlatego na podstawie uzyskanych wyników należy założyć, że czas potrzebny na wykonanie uzupełnień jest zdecydowanie dłuższy. Znając średni udział uzupełnień $\mathrm{z}$ elementów drobnowymiarowych, dodatek $\mathrm{w}$ formule kalkulacyjnej można pominąć, zwiększając nieznacznie normę czasu pracy dla muru z elementów wielkowymiarowych.

Jak już wspomniano, większość prac murarskich realizowanych jest przez niewielkie, wyspecjalizowane firmy wykonawcze, z którymi generalny wykonawca rozlicza się według kalkulacji ceny jednostkowej za murowanie. $Z$ tego względu opracowane normy nakładu pracy są wykorzystywane głównie do oszacowania czasu trwania czynności, a nie do określania kosztów robocizny. Murowanie z wykorzystaniem miniżurawia wymaga uprawnień Ż-II, co skutkuje ograniczeniem liczby firm wykonawczych przystepujących do przetargu. $\mathrm{Z}$ tego względu różnice $\mathrm{w}$ cenach ofertowych na murowanie $\mathrm{z}$ elementów drobnowymiarowych i wielkowymiarowych nie są duże. Znaczna różnica w pracochłonności robót powoduje, że murowanie z elementów wielkowymiarowych jest znacznie bardziej dochodowe.

Istnieje potrzeba dalszych badań, które pozwolą na uproszczenie formuły kalkulacyjnej i uzależnienie jej od mniejszej liczby parametrów. Dalsze badania przyczynią się do uproszczenia formuły kalkulacyjnej o nakłady potrzebne do wykonania otworów, drzwi

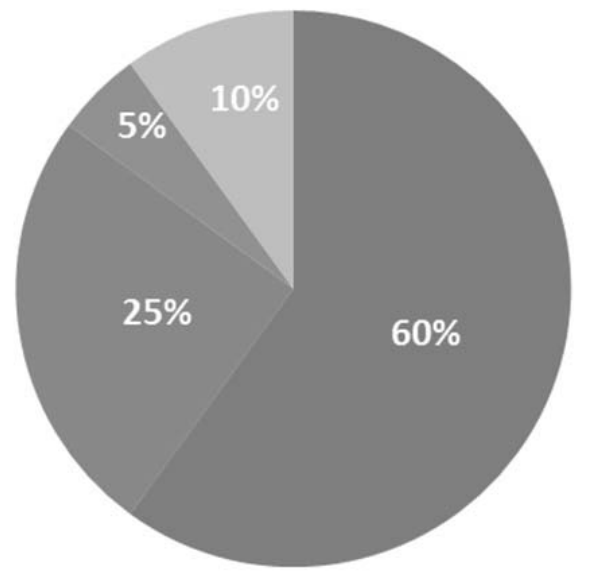

- Murowanie / Brucklaying

- Rozmieszczenie palet / Pallets arrangement

n Przygotowanie stanowiska roboczego / Working place preparation

= Przerwy na odpoczynek / Rest time

Rys. 2. Procentowy udział czasu trwania poszczególnych operacji w robotach murarskich

Fig. 2. Percentage share of duration of individual operations in bricklaying works 
Rogala, W. (2019). Wstępne badanie pracochłonności wykonania przegrody z wielkowymiarowych elementów silikatowych. Acta Sci. Pol. Architectura 18 (2), 43-50, DOI: 10.22630/ASPA.2019.18.2.21

(podając normę nakładu pracy na ścianę bez otworów i z otworami) oraz wstawek z elementów drobnowymiarowych. Formuła może mieć zatem postać:

$N_{c}{ }_{c}=k \cdot N_{c 1}$

gdzie:

$N_{c}{ }_{c}$ - norma nakładu pracy $\left[\mathrm{rbh} \cdot \mathrm{m}^{-2}\right]$,

$k$ - współczynnik zależny od wysokości ścian oraz liczby warstw uzupełniających,

$N_{c 1}$ - bazowa norma nakładu pracy, uwzględniająca dodatek na wstawki z elementów drobnowymiarowych i podana osobno dla ściany z otworami i ściany pełnej, wyznaczona dla średniej liczby wstawek i otworów w ścianach.

Współczynnik $k$ może być wyznaczony za pomocą zależności:

$k=\frac{N_{c 1} \cdot A_{2}+N_{c F} \cdot L_{F}+N_{c S} \cdot L_{S} \cdot n_{S}+N_{c C} \cdot A_{C}}{N_{c 1} \cdot A_{T}}$

gdzie:

$A_{1}$ - powierzchnia ściany bez uwzględnienia warstwy startowej i warstw uzupełniających,

$A_{r}$ - powierzchnia ściany wraz $\mathrm{z}$ warstwą startową i warstwami uzupełniającymi.

\section{WNIOSKI}

W dwóch pomiarach uzyskane dane mają nieznacznie większe wartości od tych wyliczonych na podstawie KNR K-50, w jednym przypadku czas jest krótszy. Biorąc pod uwagę, że przerwy na odpoczynek i transport palet stanowią ok. 35\% wyznaczonej normy nakładu pracy, czas murowania przegród będzie bardzo zależny od warunków organizacyjnych na budowie. Pomimo uzyskania nieznacznie dłuższych czasów murowania od wartości prezentowanych w KNR K-50, bez wątpienia murowanie $\mathrm{z}$ elementów wielkowymiarowych pozwala na znaczne skrócenie czasu prac murarskich. Szersze stosowanie technologii może przyczynić się do redukcji problemów z dosteppnościa wykwalifikowanych murarzy, ponieważ murowanie jest wtedy ponaddwukrotnie szybsze. Co więcej, największą zaletą wskazywaną przez murarzy pracujących w tej technologii jest znaczna redukcja wysiłku fizycznego. Dzięki wykorzystaniu miniżurawia podnoszenie i transport masywnych elementów murowych są wykonywane bez wysiłku fizycznego. Mając powyższe na uwadze, prognozuje się, że technologia znajdzie szersze zastosowanie $w$ niedalekiej przyszłości. Z tego względu dalsze badania przyczyniające się do weryfikacji uzyskanych wyników i określenia miarodajnej normy nakładu pracy na wykonanie murów w technologii wielkowymiarowej moga być przydatne. Dodatkowe pomiary pozwola także uprościć formułe kalkulacyjna i określić lepszą zależność nakładów koniecznych do poniesienia w zależności od sytuacji projektowej.

Z uwagi na duży udział transportu wewnętrznego, w celu optymalizacji czasu pracy murarzy, rozmieszczenie palet powinno być wykonywane przez mniej wykwalifikowanych pracowników fizycznych, którzy są bardziej dostępni na rynku pracy. Dostarczane plany montażowe mogłyby być uzupełnione o schemat rozmieszczenia palet, co umożliwiłoby częściowe przygotowanie stanowiska roboczego bez udziału murarzy. Norma nakładu pracy powinna być wówczas ustalona osobno dla murarzy i robotników.

Ograniczeniem powszechnego stosowania technologii murowania z bloków wapienno-piaskowych jest niemożliwość wykorzystania przegród jako ścian wypełniających (brak możliwości ustawienia miniżurawia po wykonaniu stropów). Powyższe oznacza, że konstrukcja musi być murowana jednocześnie z wykonywaniem szkieletu. Opracowanie schematu do obliczeń konstrukcji, który uwzględni „współpracę” muru z konstrukcją żelbetową, w znacznym stopniu może przyczynić się do upowszechnienia stosowanej technologii.

\section{PIŚMIENNICTWO}

DIN 4109:2016-07. Schallschutz im Hochbau. Teil 1: Mindestanforderungen.

Eurostat (2018). Wolne miejsca pracy, budownictwo. Pobrane z lokalizacji https://spotdata.pl/b/ogolna/utworzonemiejsca-pracy-i-ich-wykorzystanie\#/v/wolne-miejscapracy-budownictwo

Harassek, P. i Rogala, W. (2014). Zeszyt techniczny Projektowanie konstrukcyjne budynków z bloków Silka. War- 
Rogala, W. (2019). Wstępne badanie pracochłonności wykonania przegrody z wielkowymiarowych elementów silikatowych. Acta Sci. Pol. Architectura 18 (2), 43-50, DOI: 10.22630/ASPA.2019.18.2.21

szawa: Xella Polska.

Hoła, B. i Mrozowicz, J. (2003). Modelowanie procesów budowlanych o charakterze losowym. Wrocław, Dolnośląskie Wydawnictwo Edukacyjne.

KNR BC-01 (2009). Roboty budowlane w systemie YTONG. Warszawa: Bistyp Consulting.

KNR K-28 (2006). Roboty murowe w technologii SILKA E. Koszalin: Koprinet.

KNR K-50 (2013). Roboty murowe w technologii Silka Tempo. Koszalin: Koprinet.

Koper, A. (2013). Normowanie procesów monolitycznego budownictwa betonowego na potrzeby planowania robót $z$ uwzględnieniem niepewności danych (nieopublikowana rozprawa doktorska). Politechnika Warszawska, Warszawa.

Koper, A. i Marcinkowski, R. (2014). Ocena i normowanie rozwiązań technologiczno-organizacyjnych procesów budowlanych. Budownictwo i Architektura, 13 (4), 365-371.

Misiewicz, L. (2016). Rynek materiałów ściennych w Pol- sce w 2015 roku. Materiaty Budowlane, 524 (4), 66.

Misiewicz, L. (2018). Rynek materiałów ściennych w Polsce w 2017 roku. Materiały Budowlane, 548 (4), 4-5.

Nurzyński, J. (2011). Wizja rozwoju współczesnego budownictwa nakreślona $\mathrm{w}$ ramach projektu zintegrowanego ManuBuild. Prace Instytutu Techniki Budowlanej - Kwartalnik, 2 (158), 27-38.

PN-EN 1996-1-1:2015-06. Eurokod 6: Projektowanie konstrukcji murowych. Część 1-1: Reguły ogólne dla zbrojonych i niezbrojonych konstrukcji murowych.

Polska Agencja Prasowa [PAP] (2018). W budownictwie brakuje 120-150 tys. pracowników. Pobrano z lokalizacji https://budownictwo.wnp.pl/w-budownictwie-brakuje-120-150-tys-pracownikow,47807_1_0_0.html

Ustawa z dnia 26 czerwca 1974 r. Kodeks pracy. Dz.U. 1974 nr 24, poz. 141 z późn. zm.

Wielkiebudowanie.pl (2019). Rynek pracy w budownictwie. Pobrane z lokalizacji: https://www.wielkiebudowanie. pl/go.live.php/PL-H716/rynek-pracy-w-budownictwie. html

\section{INITIAL STUDY OF THE PARTITION WORKLOAD, MADE OF LARGE CALCIUM- -SILICATE MASONRY UNITS}

\section{ABSTRACT}

The paper presents a preliminary study of the labour consumption of the walls made of large-size calcium silicate masonry units. The aim of the study was to verify how long the wall erection lasts, which is made from five times larger elements than the standard used blocks and bricked with a mini-crane. Pilot studies were carried out using two methods - summary and analytical-research. The test results were referenced to existing normative. The article proposes to simplify the calculation formula, which is used to determine the labour input for bricklaying walls in the described technology.

Key words: large-size calcium silicate masonry units, normalization of workload, mechanisation of bricklaying, time of wall erection, silicates 